\title{
APLIKASI SEDIMEN DANAU TONDANO SEBAGAI MEDIA TANAM BAGI PERTUMBUHAN TANAMAN PAKCOY
}

\author{
APPLICATION OF LAKE TONDANO SEDIMENT AS A PLANTING MEDIA FOR THE \\ PAKCOY GROWTH
}

\author{
M.T.M. Sinolungan dan W.N.J. Kumolontang*) \\ *Staf Pengajar Jurusan Tanah Fakultas Pertanian Unsrat Manado
}

\begin{abstract}
Tondano Lake, one of vital natural resources at Minahasa Regency, North Sulawesi, has some functions and some problems, i.e.: sedimentation and lake shallowing. This research was conducted by using water hyacinth (Eichornia crassipes (Malt)) as compost/organic fertilizer and sediment of Tondano Lake as plant media for Packoy growth. This research has aimed to: 1) Test the composition of Tondano Lake sediment, 2) Test the composition of water hyacinth compost, and 3) Measure the growth of Pakcoy toward the given compost as a preliminary research (Pot Experiment). This was conducted: a) sediment sampling at the west part of Tondano Lake, b) sediment and compost analyses at Chemical and Soil Fertility Laboratory of Agriculture Faculty of Unsrat, c) planting Pakcoy in small pots with Group-Randomized Design for nine months in 2016. Results showed that, 1) sediment composition of Tondano Lake as the plant media has tested, 2) compost composition of water hyacinth has tested, and 3) Pakcoy growth toward the given compost as a preliminary research (Pot Experiment) has measured by height of plant, number of leaves, and freshedweight of crops, andso would applicable in further research due to the result of analyses was significantly different.
\end{abstract}

Keywords: sediment, Tondano Lake, compost, water hyacinth, pakcoy

\section{ABSTRAK}

Danau Tondano merupakan salah satu sumberdaya alam vital di Kabupaten Minahasa Provinsi Sulawesi Utara, memiliki berbagai peruntukkannya dan terdapat berbagai permasalahan, antara lain: sedimentasi dan pendangkalan danau. Penelitian ini dilakukan dengan memanfaatkan tanaman eceng gondok (Eichornia crassipes (Malt)) sebagai kompos/pupuk organik dengan sedimen Danau Tondano sebagai media tanam bagi pertumbuhan tanaman Pakcoy.Penelitian ini bertujuan untuk: 1) Menguji komposisi sedimen Danau Tondano sebagai media tanam, 2) Menguji komposisi kompos dari tanaman eceng gondok, dan 3) Mengukur pertumbuhan tanaman Pakcoy terhadap pemberian kompos sebagai penanaman awal (Percobaan Pot). Penelitian ini dilaksanakan: a) sampling sedimen di bagian barat Danau Tondano, b) analisa sedimen dan kompos di Laboratorium Kimia dan Kesuburan Tanah Fakultas Pertanian Unsrat, c)penanaman tanaman Pakcoy ditanam di pot-pot kecil dengan Rancangan Acak Kelompok selama sembilan bulan di tahun 2016. Hasil penelitian menunjukkan bahwa, 1) komposisi sedimen Danau Tondano sebagai media tanam telah teruji, 2) komposisi kompos dari tanaman eceng gondok telah teruji, and 3) pertumbuhan tanaman Pakcoy terhadap pemberian kompos sebagai penanaman awal (Percobaan Pot) telah terukur melalui tinggi tanaman, jumlah daun dan berat segar tanaman sehingga penelitian ini dapat diaplikasikan lebih lanjut oleh karena hasil analisisnya berbeda nyata.

Kata kunci: sedimen, Danau Tondano, kompos, eceng gondok, pakcoy 


\section{PENDAHULUAN}

Perairan danau merupakan salah satu bentuk ekosistem air tawar yang ada di permukaan bumi. Secara umum, danau merupakan perairan umum daratan yang memiliki fungsi penting bagi pembangunan dan kehidupan manusia. Danau Tondano merupakan salah satu sumberdaya alam vital di Kabupaten Minahasa Provinsi Sulawesi Utara, yang memiliki berbagai peruntukkannya, antara lain: sebagai sumber air (air minum, lahan pertanian, budidaya ternak, perikanan), pariwisata dan sumber pembangkit tenaga listrik (Sinolungan, et al., 2008). Dengan adanya berbagai peruntukkan Danau Tondano yang diikuti dengan pertambahan jumlah penduduk, maka semakin bertambah pula kebutuhan masyarakat terhadap sumberdaya tersebut, sehingga terdapat berbagai permasalahan, antara lain: sedimentasi dan pendangkalan danau, yang terjadi karena adanya erosi lahan di daerah tangkapan air serta lahan sempadan danau yang terakumulasi oleh endapan/sedimen pada perairan danau (Wilar dan Mandagi, 2010). Selain itu Danau Tondano banyak ditumbuhi oleh tanaman eceng gondok yang merupakan gulma air yang telah menutupi sebagian besar danau tersebut. Untuk itu perlu dilakukan penanganan dalam kondisi danau tersebut, antara lain: perlu dikelola sedimen Danau Tondano sebagai media tanam dan perlu juga dikelola tanaman eceng gondok sebagai kompos/ pupuk organik. Kedua permasalahan itulah yang difokuskan dalam penelitian ini sebagai upaya penerapan ilmu pengetahuan dan teknologi berbasis kearifan lokal yang menjadi salah satu bidang unggulan Universitas Sam Ratulangi.

Program peningkatan produksi tanaman pangan dan hortikultura untuk memenuhi kebutuhan dan memenuhi swasembada pangan di Provinsi Sulawesi Utara terus dilakukan dengan berbagai cara dan usaha, baik secara tradisional maupun modern. Peningkatan produksi pangan yang harus dicapai diharapkan selain dari segi kualitas juga dari segi kuantitas. Dalam kaitannya dengan hal ini, peran pemupukan sangat penting. Untuk meningkatkan kualitas produk, penggunaan pupuk organik sebagai substitusi pupuk kimia sangat diperlukan, karena produk yang dihasilkan bersifat organik dan bersifat ramah lingkungan melalui penerapan teknologi pengomposan. Penerapan teknologi tersebut dalam penelitian ini dilakukan dengan memanfaatkan tanaman eceng gondok (Eichornia crassipes (Malt)) sebagai kompos/pupuk organik. Media tanam yang digunakan adalah sedimen Danau Tondano. Sedimen tersebut merupakan hasil dari proses sedimentasi yang terjadi di daerah sekitar Danau Tondano. Telah banyak dilakukan penelitian di daerah tersebut, namun penelitian tentang pemanfaatan sedimen Danau Tondano sebagai media tanam bagi pertumbuhan tanaman Pakcoy (Brassica rapa L.) dengan pemberian kompos dari tanaman eceng gondok belum pernah dilakukan. Oleh sebab itu perlu dilakukan penelitian.

Tujuan penelitian ini adalah: 1) Menguji komposisi sedimen Danau Tondano sebagai media tanam; 2) Menguji komposisi kompos dari tanaman eceng gondok; 3) Mengukur pertumbuhan tanaman Pakcoy terhadap pemberian kompos sebagai penanaman awal (percobaan pot). Tanaman Pakcoy dipilih dalam penelitian ini oleh karena tanaman ini mudah tumbuh dalam kondisi apapun dan dimanapun, selain tanaman ini memiliki banyak keunggulan bagi kehidupan masyarakat, baik dikonsumsi sebagai sayuran, bagus untuk kesehatan, maupun dapat dikelola oleh masyarakat untuk dijual sehingga dapat pula meningkatkan kesejahteraan masyarakat.

\section{METODE PENELITIAN}

Penelitian ini dilaksanakan: a) sampling sedimen di bagian barat Danau Tondano, b) analisa sedimen dan kompos di Laboratorium Kimia dan Kesuburan Tanah Fakultas Pertanian Unsrat, c) penanaman tanaman Pakcoy ditanam di pot-pot kecil selama 9 (sembilan) di tahun 2016 (percobaan pot).

Bahan yang digunakan dalam penelitian adalah tanah endapan danau (sedimen dari Danau Tondano, tepatnya di Desa Talikuran Kecamatan Remboken), pasir diberi kompos/pupuk organik yang berasal dari eceng gondok dengan dosis 0 , 10, 20, dan 30 ton/ha, dimana perbandingan sedimen dan kompos telah ditentukan takarannya. Bahan kimia untuk analisis tanah dan kompos. Benih yang digunakan adalah benih tanaman Pakcoy. 
Alat yang digunakan dalam penelitian yaitu: perahu, Grab sampler, alat ukur multifungsi, ember, loyang besar, gayung, wadah plastik, meteran, oven, timbangan, sekop, pot kecil (pot percobaan), dan alat-alat laboratorium.

Variabel yang diamati adalah komposisi sedimen danau; komposisi unsur hara di kompos sebelum perlakuan dan penanaman, yakni: Corganik, kandungan $\mathrm{N}, \mathrm{P}$, dan $\mathrm{K}$; varibel partumbuhan tanaman, yakni:jumlah daun,tinggi tanaman, berat segar tanaman.

\section{Metode Penelitian}

Metode penelitian dilakukan dengan Metode Purposive Sampling dan eksperimen menggunakan Rancangan Acak Kelompok (RAK) dengan Perlakuan:

$A=$ Kontrol (tanpa kompos)

$\mathrm{B}=$ Kompos Eceng gondok 10 ton/ha

$C=$ Kompos Eceng gondok 20 ton/ha

$\mathrm{D}=$ Kompos Eceng gondok 30 ton/ha.

Penelitian dilakukan dalam 3 takaran kompos sehingga diperoleh 9 pot dengan kompos, dan tanpa kompos sebanyak 3 pot, sehingga total pot percobaan sebanyak 12 pot yang dirancang dalam kelompok.

\section{Prosedur Kerja \\ Pra-survei}

Dilakukan survei awal dalam penentuan lokasi sampling sedimen danau, baik dalam sampling sedimen dan sampling tanaman eceng gondok di Danau Tondano.

\section{Tahap Sampling}

Dilakukan untuk pengambilan sampel sedimen di bagian barat Danau Tondano yakni di Desa Talikuran Kecamatan Remboken. Sampling sedimen menggunakan perahu dan sedimen dikeruk dengan alat Grab sampler pada dasar sedimen danau.

Dilakukan pengambilan tanaman eceng gondok yang ada di sekitar danau tersebut sebagai material dalam pembuatan kompos.

\section{Penyiapan Sedimen sebagai Media Tanam}

Sedimen danau dikering-anginkan untuk disiapkan sebagai media tanam/tanah bagi pertumbuhan tanaman. Perlu juga dianalisa komposisi sedimen sebelum ditanami oleh tanaman.

\section{Pembuatan Kompos}

Kompos dibuat dengan cara: diambil tanaman eceng gondok yang tumbuh di sekitar lokasi sampling sedimen danau. Tanaman tersebut kemudian dikering-anginkan, dipotong-potong, dioven, dan dibiarkan sampai menjadi lapuk dan berwarna coklat. Pembuatan kompos dilakukan secara fermentasi dengan menggunakan EM4 selama 3-4 minggu (matang). Setelah kompos matang kemudian dianalisis kadar unsur haranya.

\section{Penanaman Tanaman Pakcoy}

Dilakukan pembibitan tanaman pakcoy. Tanah yang diberi kompos/pupuk organik dimasukkan ke dalam pot-pot percobaan kemudian disirami/ inkubasi selama beberapa hari. Setelah diinkubasi diadakan penanaman. Setelah 7 hari penanaman, dilakukan penjarangan dimana setiap pot dibiarkan 3 tanaman. Dilakukan pemeliharaan tanaman. Kemudian diamati pertumbuhan tanamannya tiap minggu.

\section{Analisa Data}

Data ditabulasi dan dianalisis dengan menggunakan Analisis Sidik Ragam dan bila berpengaruh dilanjutkan dengan Uji BNT 5\%.

\section{HASIL DAN PEMBAHASAN}

\section{Komposisi Sedimen Danau Tondano sebagai Media Tanam}

Hasil analisis secara fisik dari sedimen Danau Tondano, berupa: 1) ukuran partikel sedimen yang tersusun atas: Pasir $=10.25 \%$, Debu $=$ $64.32 \%$, Liat $=25.43 \%$ dengan Tekstur: Lempung Berdebu; 2) kadar air sedimen awal $=509.17 \%$.

Hasil analisis secara kimianya, berupa: kandungan hara dari sedimen tertera pada Tabel 1 . 
Tabel 1. Kandungan Hara Endapan Sedimen Danau Tondano

(Table 1. Nutrient Content of Tondano Lake Sediment)

\begin{tabular}{llll}
\hline \multicolumn{1}{c}{ Jenis Analisis } & \multicolumn{1}{c}{ Hasil Analisis } & \multicolumn{1}{c}{ Metode Analisis } & \multicolumn{1}{c}{ Keterangan } \\
\hline $\mathrm{pH} \mathrm{H}_{2} \mathrm{O}$ & 6.6 & $\mathrm{pH}$ meter & Netral \\
$\mathrm{C}$-org $(\%)$ & 8.9 & Walkey and Black & Sangat Tinggi \\
$\mathrm{N}$-total $(\%)$ & 0.5 & Kjeldhal & Sedang \\
P-tersedia (ppm) & 11,12 & Bray 1 & Rendah \\
K-tersedia (ppm) & 10,74 & Bray 1 & Rendah \\
KTK (me/100 g tanah) & 20,84 & $\mathrm{NH}_{4} \mathrm{Ac}$ & Sedang \\
\hline
\end{tabular}

Tabel 1 menunjukkan bahwa kandungan hara $\mathrm{N}$ tergolong tinggi dan $\mathrm{C}$-organik yang sangat tinggi. Keadaan ini terjadi karena daerah pengambilan sampel telah banyak ditumbuhi oleh eceng gondok dan adanya yang telah membusuk dan kemungkinan mengendap. Selain ini endapan yang juga kemungkinan disebabkan oleh adanya masyarakat yang ada di sekitar danau yang menggunakan danau sebagai sarana pembuangan akhir serta adanya ternak peliharaan di sekitar danau. Kandungan $\mathrm{P}$ dan $\mathrm{K}$ tergolong rendah hal ini kemungkinan besar tidak tersedia atau mungkin terjadi fiksasi. Oleh karena itu memungkinkan penambahan $P$ untuk meningkatkan jumlah $P$ yang tersedia (Subandi, 1982). Menurut Soepardi (1983), pemberian $P$ yang cukup dapat memberikan pengaruh yang menguntungkan ada pembentukan bunga, buah dan biji, kematangan tanaman, perkembangan akar halus dan akar rambut serta kualitas tanaman yang baik.

Kapasitas Tukar Kation (KTK) tergolong sedang serta $\mathrm{pH}$ tanah yang tergolong netral. Kandungan hara yang demikian memungkinkan untuk diadakan budidaya tanaman yang dapat membantu masyarakat sekitar danau, untuk memanfaatkan sedimen sebagai media tanam baik tanaman sayuran, obat dan tanaman hias. Kandungan hara menjadi petunjuk untuk mengadakan tindakan pemupukan sehingga produksi tanaman dapat meningkat. Hal itu didukung pula oleh Sinolungan dan Kaunang (2014), bahwa sedimen danau dapat dijadikan sebagai media tanam bagi pertumbuhan suatu jenis tanaman.

\section{Komposisi Kompos dari Tanaman Eceng Gondok}

Kandungan hara kompos yang digunakan yaitu kompos Eceng Gondok tertera pada Tabel 2.

Kandungan hara kompos eceng gondok tersebut menunjukkan bahwa ratio $\mathrm{C} / \mathrm{N}=12.42$. Nilai ini berarti telah memenuhi syarat standar pupuk organik yang ditetapkan. Hal ini didukung oleh Sutanto (2002) yang menyatakan bahwa bahan organik yang mengalami proses pengomposan baik dan telah menjadi pupuk organik yang stabil mempunyai rasio $\mathrm{C} / \mathrm{N}$ antara 10-15. Sumarto (1992) dalam Sutanto (2002) pula menyatakan bahwa kompos yang bermutu dan benar-benar matang memiliki rasio $\mathrm{C} / \mathrm{N}$ kurang dari 20. Kandungan hara yang ada dalam kompos tersebut dapat membantu menyumbangkan kebutuhan tanaman dalam proses yang berlangsung untuk pertumbuhan vegetatif hingga produksi tanaman.

\section{Pertumbuhan Tanaman Pakcoy terhadap Pemberian Kompos sebagai Penanaman Awal (Percobaan Pot)}

\section{Tinggi Tanaman}

Hasil pengukuran rata-rata tinggi tanaman pada setiap minggu pengamatan tertera pada Tabel 3. 
Tabel 2. Kandungan Hara Kompos Eceng Gondok

(Table 2. Nutrient Content of Water Hyacinth Compost)

\begin{tabular}{|c|c|}
\hline Komposisi & Hasil Analisis \\
\hline $\mathrm{N}(\%)$ & 1,44 \\
\hline P-tersedia (ppm) & 30.23 \\
\hline K-tersedia (ppm) & 27.00 \\
\hline $\mathrm{pH}$ & 6.4 \\
\hline C-organik (\%) & 17.89 \\
\hline
\end{tabular}

Tabel 3. Rata-rata Tinggi Tanaman pada Setiap Minggu Pengamatan

(Table 3. Mean of Height Plant in Every Week Observation)

\begin{tabular}{cccccc}
\hline PERLAKUAN & $1 \mathrm{MST}$ & $2 \mathrm{MST}$ & $3 \mathrm{MST}$ & $4 \mathrm{MST}$ & $5 \mathrm{MST}$ \\
\hline MO & 0.9 & $2.3 \mathrm{a}$ & $5.6 \mathrm{a}$ & $7.1 \mathrm{a}$ & $9.9 \mathrm{a}$ \\
M1 & 1 & $3.23 \mathrm{~b}$ & $8.16 \mathrm{~b}$ & $12.1 \mathrm{~b}$ & $15.3 \mathrm{bc}$ \\
M2 & 1 & $3.53 \mathrm{~b}$ & $8.25 \mathrm{~b}$ & $13.16 \mathrm{~b}$ & $14.98 \mathrm{~b}$ \\
M3 & 0.9 & $4.06 \mathrm{c}$ & $11.51 \mathrm{c}$ & $14.53 \mathrm{c}$ & $16.25 \mathrm{c}$ \\
\hline BNT 5 \% & & 0.585 & 1.56 & 1.326 & 1.101
\end{tabular}

Keterangan: Angka-angka yang diikuti huruf yang sama tidak berbeda nyata pada taraf 5\%

Hasil analisis sidik ragam menunjukkan bahwa, pada 1 MST belum ada pengaruh nyata dalam pemberian kompos terhadap tinggi tanaman. Hal ini disebabkan tanaman belum mengambil unsur hara dari dalam tanah, tetapi pertumbuhan awal kecambah masih menggunakan sumber makanan yang ada dalam benih tersebut. Gardner, et al. (1991) menyatakan bahwa pertumbuhan dan hasil suatu tanaman dipengaruhi oleh keadaan lingkungan tumbuhnya. Salah satu faktor lingkungan tumbuh yang penting bagi pertumbuhan tanaman adalah ketersediaan unsur hara dan pengendalian organisme pengganggu tanaman. Pada minggu selanjutnya yakni minggu ke-2 hingga ke-5 pemberian kompos memberikan pengaruh nyata pada pertumbuhan tinggi tanaman. Adanya pengaruh yang nyata selanjutnya dianalisis setiap perlakuan, dimana terjadi perbedaan yang nyata dengan uji lanjut yakni Uji BNT 5\%.

Hasil Uji BNT 5\% menunjukkan perlakuan tanpa pemberian pupuk berbeda dengan adanya perlakuan dengan pupuk, dan nilai tertinggi berada pada perlakuan M3 yaitu 30 ton/ha. Keadaan ini menunjukkan bahwa pemberian pupuk dengan dosis 30 ton/ha mampu menyumbangkan hara yang dibutuhkan tanaman. Tanaman akan tumbuh baik jika kebutuhan hara terpenuhi. Tanaman sayuran sangat membutuhkan unsur $\mathrm{N}$ yang cukup untuk pertumbuhan vegetatif yang berpengaruh pada fase generatif (Hardjowigeno, 2003). Nitrogen pada tanaman merupakan unsur hara makro yang penting bagi pertumbuhan dan perkembangan tanaman, tetapi ketersediaannya dalam tanah terbatas. Oleh sebab itu, untuk mengatasi kekurangan $\mathrm{N}$ pada tanaman, perlu dilakukan pemupukan. Tanaman menyerap $\mathrm{N}$ dalam bentuk $\mathrm{NH}_{4}{ }^{+}$dan $\mathrm{NO}_{3}{ }^{-}$. Penggunaan bentuk $\mathrm{N}$ dalam tanah dipengaruhi $\mathrm{pH}$ tanah. Pada tanah-tanah masam tanaman menggunakan $\mathrm{N}$ dalam bentuk $\mathrm{NH}_{4}{ }^{+}$,karena nitrifikasi kurang berlangsung pada $\mathrm{pH}$ di bawah 5,5. Namun perlu diperhatikan bahwa kemampuan tanah mengadsorpsi $\mathrm{NH}_{4}{ }^{+}$akan menurun dengan menurunnya $\mathrm{pH}$ tanah sehingga ion ini akan mudah tercuci (Bohn, et al., 1979). Masalah fosfor terpenting yaitu sebagian besar fosfor tidak tersedia bagi tanaman dan bila fosfor yang larut diberikan ke tanah sebagian difiksasi sehingga menjadi tidak tersedia bagi tanaman (Soepardi, 1983). Unsur P dalam tanaman berada dalam nukleus, sehingga pembentukan dan pembelahan sel tidak mungkin berlangsung tanpa $P$ yang cukup (Follet, et al., 1981).

\section{Jumlah Daun}

Hasil pengukuran jumlah daun pada setiap minggu pengamatan tertera pada Tabel 4 . 
Tabel 4. Rata-rata Jumlah Daun pada Setiap Minggu Pengamatan

(Table 4. Mean of Number of Leaves in Every Week Observation)

\begin{tabular}{cccccc}
\hline PERLAKUAN & 1 MST & 2 MST & 3MST & 4 MST & 5MST \\
\hline MO & 2 & 3.6 & 5.3 & 6.3 & $6.3 \mathrm{a}$ \\
M1 & 2.3 & 3.6 & 6 & 6.3 & $8.3 \mathrm{~b}$ \\
M2 & 2.6 & 4 & 66.6 & 7 & $8 \mathrm{~b}$ \\
M3 & 2.3 & 4 & 7 & 7.3 & $9 \mathrm{~b}$ \\
\hline BNT & & & & & 1.2 \\
\hline
\end{tabular}

Keterangan: Angka-angka yang diikuti huruf yang sama tidak berbeda nyata pada taraf $5 \%$

Hasil analisis sidik ragam menunjukkan bahwa pada 1 sampai 4 MST tidak ada pengaruh nyata dalam pemberian kompos pada jumlah daun tanaman. Hal ini kemungkinan jumlah daun tidak bertambah, tetapi ukuran dan ketebalan daun yang bertambah. Pengaruh nyata pemberian kompos nanti terlihat pada $5 \mathrm{MST}$ dan ini hanya nyata pada perlakuan tanpa diberi pupuk dan dengan diberi pupuk, sedangkan antar perlakuan yang diberi pupuk tidak terlihat perbedaan yang nyata.

Pertumbuhan tanaman dalam hal ini jumlah daun sangat ditentukan oleh jumlah hara tersedia dalam tanah. Tanaman pada pertumbuhan awal (vegetatif) sangat membutuhkan unsur hara dalam pembentukan jaringan.

Hardjowigeno (2003) mengemukakan bahwa Nitrogen berfungsi mempercepat pertumbuhan vegetatif tanaman dan sebagai bahan pembentuk protein. Protein yang dibentuk kemudian digunakan untuk pembentukan protoplasma dalam sel-sel tanaman sehingga terjadi pembelahan sel. Hal ini selanjutnya berpengaruh pada penambahan jumlah daun. Pada umumnya pupuk organik mengandung unsur hara lebih lengkap yaitu unsur hara makro dan mikro meskipun dalam jumlah yang sedikit. Pemberian pupuk organik ke dalam tanah membawa dampak positif bagi tanah dan tanaman. Peran bahan organik terhadap sifat fisik tanah diantaranya merangsang granulasi, memperbaiki aerasi tanah dan meningkatkan kemampuan menahan air. Peran bahan organik terhadap sifat biologis tanah adalah meningkatkan aktivitas mikroorganisme yang berperan pada fiksasi nitrogen dan transfer hara tertentu seperti N, P dan S. Peran bahan organik terhadap sifat kimia tanah adalah meningkatkan kapasitas tukar kation (KTK) sehingga mempengaruhi serapan hara oleh tanaman (Gaur, 1980).

\section{Berat Segar Tanaman}

Hasil pengukuran berat segar tanaman di saat panen tertera pada Tabel 5. Hasil analisis sidik ragam menunjukkan adanya pengaruh nyata dalam pemberian pupuk pada berat segar tanaman. Selanjutnya, hasil uji BNT 5\% menunjukkan tanaman tanpa pemberian kompos berbeda nyata dengan yang diberi kompos, dan antar perlakuan 10 ton/ha, dan 20 ton/ha tidak berbeda nyata namun dengan perlakuan 30 ton/ha berbeda nyata. Hasil analisis sidik ragam menunjukkan bahwa, pada 1 MST belum ada pengaruh nyata dalam pemberian kompos pada tinggi tanaman. Hasil ini membuktikan bahwa tanaman sangat membutuhkan hara dalam proses pertumbuhan dan perkembangannya.

Hardjowigeno (2003) menyatakan bahwa kekurangan hara dalam hal ini $\mathrm{N}$ tanah menyebabkan pertumbuhan kerdil dan pertumbuhan akar terbatas. Kandungan $\mathrm{K}$ yang sangat rendah dalam tanah juga menyebabkan fungsi $\mathrm{K}$ dalam tanah untuk mentranslokasikan hara yang lain ke jaringan tanaman tidak berjalan dengan baik. Selain itu unsur $\mathrm{P}$ dan $\mathrm{K}$ sangat dibutuhkan dalam pembentukan protein, karbohidrat, dan perkembangan akar tanaman. Akar tanaman yang berkembang baik mengakibatkan penyerapan hara dan air berlangsung baik akibatnya pertumbuhan tanaman baik. $\mathrm{Ca}$ juga berguna untuk penyusun dinding sel tanaman, pembelahan sel dan untuk tumbuh (elongation). Jika kekurangan Kalsium, maka tunas dan akar tidak dapat tumbuh karena pembelahan sel terhambat. 
Tabel 5. Rata-rata Berat Segar Tanaman pada Saat Panen

(Table 5. Mean of Freshed Weight of Crops on Harvesting Time)

\begin{tabular}{cc}
\hline PERLAKUAN & BERAT SEGAR TANAMAN \\
\hline MO & $24.6 \mathrm{a}$ \\
M1 & $47.6 \mathrm{~b}$ \\
M2 & $49.3 \mathrm{~b}$ \\
M3 & $62.2 \mathrm{c}$ \\
\hline BNT & 17.04
\end{tabular}

Keterangan: Angka-angka yang diikuti huruf yang sama tidak berbeda nyata pada taraf5 \%

\section{KESIMPULAN}

Komposisi sedimen Danau Tondano sebagai media tanam telah teruji (C-organik sangat tinggi, $\mathrm{N}$-total sedang, $\mathrm{P}$ dan $\mathrm{K}$-tersedia rendah, dan KTK sedang).

Komposisi kompos dari tanaman eceng gondok telah teruji $(\mathrm{N}=1.44$, P-tersedia= 30.23 , $\mathrm{K}$ tersedia=27, C-organik= 17.89).

Respon pertumbuhan tanaman Pakcoy terhadap pemberian kompos sebagai penanaman awal (Percobaan Pot) menunjukkan berbeda nyata pada perlakuan M3 (30 ton/ha).

\section{DAFTAR PUSTAKA}

Bohn, H.L., B.L. McNeal and G.A. O'Connor. 1979. Soil Chemistry. John Wiley and Sons,USA.

Follett, R.H.L., S. Murphy and R.L. Donahue. 1981. Fertilizers and Soil Amendments. PrenticeHall Inc. Englewood Cliffs. New Jersey

Gardner, F.P., R.B. Peance, and R.L. Mitchell. 1991. Fisiologi Tanaman Budidaya. Universitas Indonesia. Jakarta.

Gaur, D.C. 1980. Present Status of Composting and Agricultural Aspect, in: Hess,P.R. (ed). Improving Soil Fertility Through Organic Recycling, Compost Technology. FAO of United Nation, New Delhi.

Hardjowigeno, S. 2003. IImu Tanah. Akademika Pressindo. Jakarta.
Sinolungan, M.T.M., T. Koumoto, F. Kondo. and Y. Zhao. 2008. The geochemical characteristics of sediment in Tondano Lake, Indonesia: heavy metals and organic matter contents, and grain size distribution. Paddy Water Environ, 6 (3): 341-348.

Sinolungan, M.T.M., dan Dj. Kaunang. 2014. Prospek Pengembangan Solidifikasi Sedimen Tondano dengan Campuran Flyashbased Geopolymer. Laporan Penelitian Riset Unggulan Unsrat Tahun 2014. Lembaga Penelitian Unsrat Manado.

Soepardi, G. 1983. Sifat dan Ciri Tanah. Departemen IImu Tanah.Fakultas Pertanian, IPB. Bogor.

Subandi, B. 1982. Pengaruh Pemupukan N dan P terhadap Pertumbuhan dan Produksi Tanaman Jagung, Tesis. Departemen IImu Tanah. Fakultas Pertanian, IPB. Bogor.

Sutanto, R. 2002. Penerapan Pertanian Organik. Kanisius. Yogyakarta.

Wilar, B. dan J. Mandagi. 2010. Rencana Tindak Pengelolaan Danau Tondano Pemerintah Kabupaten Minahasa-Badan Perencanaan Pembangunan Penelitian dan Pengembangan Daerah. Tondano 
